\title{
ADIPOR2 Gene
}

National Cancer Institute

\section{Source}

National Cancer Institute. ADIPOR2 Gene. NCI Thesaurus. Code C103976.

This gene plays a role in adiponectin binding and ligand-mediated signaling. 